\title{
INDIGENOUS KNOWLEDGE OF MEDICINAL PLANTS AMONG DAO AND MUONG ETHNIC MINORITY GROUPS IN BA VI NATIONAL PARK, HANOI
}

\author{
Hoang Van Sam \\ Vietnam Forestry University, hoangvsam@yahoo.com
}

\begin{abstract}
This paper presents a survey the medicinal plants and their traditional use by Muong and Dao ethnic minority groups in Ba Vi National park, Vietnam. A total of 257 medicinal plant species belonging to 204 genera and 81 families are used by Dao and Muong people in Ba Vi National Park. These species are used for treatment of 63 different diseases. Of them, the Dao ethnic group used 144 species, the Muong ethnic group used 30 species, and 83 species were used by both ethnic minority groups. Women in Ba Vi National Park are mainly responsible for the health care of their household, so they have better knowledge of medicinal plants than men and are also mainly engaged in collecting medicinal plants. The Dao ethnic group has better knowledge and experience of medicinal plants than the Muong, and they use much more species for diseases treatment compared with the Muong people in the research area. Knowledge about using medicinal plants to treat disease is also a difference. 83 species have similar medicinal uses among the two groups, while there are 11 species having at least one medical use the same among the Muong and Dao, although one of the groups may also use it for other treatments. An additional 23 medicinal plant species are used by both the Muong and Dao, but there are no similarities in the medicinal uses.
\end{abstract}

Key words: Dao ethnic group, indigenous knowledge, medicinal plant, Muong ethnic group, Ba Vi National Park.

\section{INTRODUCTION}

Man is known to have utilized plants as a source of medicinal drugs for thousands of years. Medicinal plants are potential sources of new drugs and hold a great value for developing pharmaceutical products, phytomedicines, and dietary supplements Hoang et al. (2008) [7]. About $80 \%$ of the world's population relies on traditional medicine. Although in many communities medicinal plants are the only available source for medical treatment van Andel (2000) [9], Hoang et al. (2008) [7], local indigenous remedies are less used now than before. In many tropical regions indigenous knowledge is at risk of extinction just as is biodiversity itself Slikkerveer (1999) [8]. Vietnam is a rich country of biodiversity, which has a high potential of medicinal plants. This source is not only diverse in number of species but also diverse in the treatment capability. However, until now, people's knowledge of these species is limited, and there are many more medicinal plant species in nature that people either do not know about, or have limited knowledge of their applicability. Ba Vi National park, one of the 30 National Parks in
Vietnam was established in 1992. It is located in Ha Noi (about $50 \mathrm{~km}$ from centre Ha Noi). There is a population of some 46,000 people living in the park, belonging to Kinh, Muong, and Dao groups. The Kinh are the major group, while the Dao and Muong are ethnic minority groups. This study focuses on traditional medicinal plants used by the Muong and Dao groups, who are the major users of medicinal plants in the park. The study deals with the variety of medicinal plant species and their uses recorded during a 6 month survey of traditional medicinal plants in that area.

\section{METHODOLOGY}

Household surveys and interviews were carried out in 100 randomly selected households. The standard interviews contained specific questions on age, gender, and ethnic background of the gatherers and main users of plant products Martin (1995) [5]. Additionally, Trips were organized with indigenous experts, e.g., traditional healers, village elders, and other local people who knew about medicinal plants to determine which plant species areharvested and for what purpose in the forests. 
All plants considered by local people to have medicinal properties were collected and identified. These plants not only included wild species but also cultivated plants and wild plants that had been taken from the forest and planted in gardens. The specimens were deposited at the Biodiversity Centre of the Vietnam Forestry University. Plant species were identified by experts at the Biodiversity Centre and double checked in the following literatures Chi (1996) [1], Ho (2000) [2], Hung et al. (2007) [4], Loi (1995) [4] and van Valkenburg (2001) [10].

The importance of medicinal plant species was identified using standard Participatory Rural Appraisal (PRA) techniques Ngai (2001) [6], Martin (1995) [5] where local people were asked to rank a list of regularly used local medicinal plants.

\section{RESULTS}

\section{Diversity of medicinal plants}

A total of 257 medicinal plant species belonging to 204 genera and 81 families are used by Dao and Muong ethnic minority groups in $\mathrm{Ba} \mathrm{Vi}$ National Park. These species are involved in 313 different treatments. The Dao ethnic group uses 144 species, while the Muong ethnic group uses 30 species. 83 species are used by both ethnic minority groups. For most species only one recipe was mentioned; some have multiple medicinal applications. Most of the medicinal plant species in $\mathrm{Ba}$ Vi National
Park are angiosperms; only 1 species belongs to the gymnosperms, and 2 species are ferns.

Among the 257 species of medicinal plants used by the Dao and Muong ethnic groups in Ba Vi National Park, $74 \%$ of the species were collected from the wild, $11 \%$ of the species were both taken from the forest and grown in home gardens and agricultural fields, $15 \%$ of the species were cultivated only in home gardens. This practice helps to develop medicinal plant resources, and also makes them more widely available, especially when derived from rare and endangered species.

\section{Diversity of plant parts used}

Different plant parts are used to treat different diseases. Some medicinal plant species have only one component that can be used, while for other species several components or the whole plant can be used for disease treatment. In Ba Vi National Park, the Dao and Muong people used the whole plant for disease treatment with 15 species, while for the other species only one, two, three or four components are be used to treat diseases.

Leaves are most commonly used with $56.4 \%$ of the total species. Roots and rhizomes are the second important part with $37.4 \%$. Stems are also commonly used by the Dao and Muong. The smallest part is the bulb, with only 3 medicinal plant species used for disease treatment. The diversity of parts used is indicated in table 1 .

Table 1. Diverse parts of medicinal plants used by Dao and Muong people in Ba Vi National Park

\begin{tabular}{|c|c|c|}
\hline Part of plant & Number of species & Percent of total \\
\hline Leaves & 145 & 56.4 \\
\hline Root, rhizome & 96 & 37.4 \\
\hline Stem & 74 & 28.8 \\
\hline Bark & 33 & 12.8 \\
\hline Fruit & 17 & 6.6 \\
\hline Whole plant & 15 & 5.8 \\
\hline Seed & 7 & 2,7 \\
\hline Tuber & 7 & 2.7 \\
\hline Flower & 6 & 2.3 \\
\hline Bulb & 3 & 1.2 \\
\hline
\end{tabular}




\section{Diseases treated with medicinal plants}

The 257 medicinal plant species in $\mathrm{Ba} \mathrm{Vi}$ National Park are used by the Dao and Muong for treatment of 63 different diseases. There are 24 diseases for which local people use only one medicinal plant. For seven diseases local people use two plant species for treatment, while for five diseases local people use three plant species. The highest number of species are used to treat weakness (tonic), stomachache, dysentery, diarrhea, flu, indigestion, and snake bite (table 2).

Table 2. Number of family, genus, and plant species used for different illnesses in Ba Vi National Park by Muong and Dao people

\begin{tabular}{|c|c|c|c|}
\hline Medicinal application & Number of family & Number of genus & Number of species \\
\hline Tonic & 21 & 31 & 32 \\
\hline Stomachache & 18 & 22 & 24 \\
\hline Dysentery & 17 & 20 & 21 \\
\hline Diarrhea & 9 & 11 & 17 \\
\hline Flu & 13 & 14 & 15 \\
\hline Indigestion & 13 & 13 & 14 \\
\hline Snakebite & 12 & 14 & 14 \\
\hline Toothache & 10 & 14 & 14 \\
\hline Rheumatism & 11 & 13 & 13 \\
\hline Wounds & 11 & 13 & 13 \\
\hline Cold & 9 & 9 & 12 \\
\hline Itches & 9 & 11 & 12 \\
\hline Malaria & 9 & 10 & 12 \\
\hline Bone fractures & 8 & 9 & 9 \\
\hline Headache & 7 & 9 & 9 \\
\hline Arthritis & 6 & 8 & 8 \\
\hline Detoxification & 8 & 8 & 8 \\
\hline Haemostatic & 5 & 5 & 7 \\
\hline High blood pressure & 6 & 7 & 7 \\
\hline Oedema & 7 & 7 & 7 \\
\hline Fever & 6 & 6 & 6 \\
\hline Infection & 6 & 6 & 6 \\
\hline Irregular menses & 4 & 5 & 6 \\
\hline Coughs & 5 & 5 & 5 \\
\hline Hemorrhage & 1 & 1 & 4 \\
\hline Kidney failure & 4 & 4 & 4 \\
\hline Sores & 4 & 4 & 4 \\
\hline Back pain & 3 & 3 & 3 \\
\hline Burns & 3 & 3 & 3 \\
\hline Hookworm & 2 & 3 & 3 \\
\hline Liver & 3 & 3 & 3 \\
\hline Sore throat & 3 & 3 & 3 \\
\hline Allergies & 2 & 2 & 2 \\
\hline Anodyne & 2 & 2 & 2 \\
\hline Aphrodisiacs & 1 & 1 & 2 \\
\hline Colitis & 2 & 2 & 2 \\
\hline Menorrhagia & 2 & 2 & 2 \\
\hline Risk of miscarriage & 2 & 2 & 2 \\
\hline
\end{tabular}




\begin{tabular}{|l|l|l|l|}
\hline Sunburn & 1 & 1 & 2 \\
\hline Aphasia & 1 & 1 & 1 \\
\hline Cancer & 1 & 1 & 1 \\
\hline Constipation & 1 & 1 & 1 \\
\hline Diabetes & 1 & 1 & 1 \\
\hline Dyspnoea & 1 & 1 & 1 \\
\hline Enteritis & 1 & 1 & 1 \\
\hline Eye sores & 1 & 1 & 1 \\
\hline Food poisoning & 1 & 1 & 1 \\
\hline Helminthiasis & 1 & 1 & 1 \\
\hline Herpes & 1 & 1 & 1 \\
\hline Hiccups & 1 & 1 & 1 \\
\hline Icterus & 1 & 1 & 1 \\
\hline Leprosy & 1 & 1 & 1 \\
\hline Lost voice & 1 & 1 & 1 \\
\hline Measles & 1 & 1 & 1 \\
\hline Metritis & 1 & 1 & 1 \\
\hline Mumps & 1 & 1 & 1 \\
\hline Nervous debility & 1 & 1 & 1 \\
\hline Pneumonia & 1 & 1 & 1 \\
\hline Skin diseases & 1 & 1 & 1 \\
\hline Splenitis & 1 & 1 & 1 \\
\hline Styptic & 1 & 1 & 1 \\
\hline Tuberculosis & 1 & & 1 \\
\hline Urinating problems & 1 & 1 & 1 \\
\hline & & 1 & 1 \\
\hline
\end{tabular}

\section{Who is collecting medicinal plants?}

From interviewing households and key informants, it emerged that women collect medicinal plants more than men at almost every age level, especially in the age classes over 26 years old. This indicates that women are mainly responsible for health care. Young people are rarely engaged in collecting medicinal plants (table 3).

Differences between Dao and Muong Ethnic groups on using medicinal plants

\section{Number of medicinal plant species}

A total of 257 medicinal plant species are used by Muong and Dao people in $\mathrm{Ba} \mathrm{Vi}$ National Park. Of them 144 species are used by the Dao, 30 species are used by the Muong, and 83 species used by both ethnic groups (table 4). The Dao ethnic group has better knowledge on using medicinal plant than the Muong, and they also have much experience collecting and trading medicinal plants. Most traditional healers in Ba Vi National Park belong to the
Dao ethnic group.

Table 3. Percentage of gender and age level of Muong and Dao in $\mathrm{Ba} \mathrm{Vi}$ National Park harvesting medicinal plants

\begin{tabular}{|c|c|c|}
\hline Age & Gender & Percentage (\%) \\
\hline \multirow{2}{*}{$>50$} & Male & 15 \\
\cline { 2 - 3 } & Female & 34 \\
\hline \multirow{2}{*}{$26-50$} & Male & 13 \\
\cline { 2 - 3 } & Female & 27 \\
\hline \multirow{2}{*}{$16-25$} & Male & 4 \\
\cline { 2 - 3 } & Female & 4 \\
\hline \multirow{2}{*}{$<16$} & Male & 1 \\
\cline { 2 - 3 } & Female & 2 \\
\hline \multicolumn{2}{|c|}{ Average \% of Males } & 33 \\
\hline \multicolumn{2}{|c|}{ Average \% of Females } & 67 \\
\hline
\end{tabular}

\section{Different knowledge of medicinal uses}

Among the Muong and Dao ethnic groups, there is not only a different number of medicinal plant species used, but also different uses of medicinal plants for disease treatment. 
A total of 83 plant species (32\%) are used by both Muong and Dao to treat the same diseases. The remaining species are used for totally different or only partly similar disease treatment.

There are 11 species having at least one similar medical use among the Muong and Dao, but one of them (Muong or Dao) still has at least one additional medical use. For example, both the Dao and Muong use Kyllinga monocephala to treat flu and fever, but only the Dao use it to treat skin diseases. Both the Muong and Dao use Plantago asiatica (Plantaginaceae) to treat flu, but only the Dao use it to treat kidney failure; both the Muong and Dao use Asparagus cochinchinensis (Asparagaceae) to treat tuberculosis, but only the Dao use it to treat snakebite. Both the Muong and Dao use Clerodendrum fragrans (Verbenaceae) to treat irregular menses, haemostatic, but only the Muong use it to treat rheumatism

Table 4. Number of taxa used by Muong and Dao people

\begin{tabular}{|l|c|c|c|}
\hline \multicolumn{1}{|c|}{ Taxa } & Dao & Dao, Muong & Muong \\
\hline Species & 144 & 83 & 30 \\
\hline Genus & 127 & 76 & 30 \\
\hline Family & 67 & 50 & 25 \\
\hline
\end{tabular}

A total of 23 medicinal plant species are used by both the Muong and Dao, but there are no similarities in the medicinal uses. For example, the Dao use Gnetum montanum (Gnetaceae) fruits to treat Detoxification, but the Muong use its leaves to treat snakebite. The Dao use Catharanthus roseus (Apocynaceae). roots and stems to treat high blood pressure, but the Muong use its leaves to treat irregular menses; The Dao use Antidesma ghaesembilla (Euphorbiaceae) leaves and bark to treat cough and rheumatism, while the Muong use the bark to treat headache.

\section{CONCLUSIONS}

A total of 257 medicinal plant species belonging to 204 genera and 81 families are used by the Dao and Muong people in Ba Vi National Park. These species are used for treatment of 63 different diseases. The Dao ethnic group uses 144 species, the Muong ethnic group uses 30 species, and 83 species are used by both groups.

Women in Ba Vi National Park are mainly responsible for the health care of their household, and they have better knowledge of medicinal plants than men and are also mainly engaged in collecting medicinal plants.

The Dao ethnic group has better knowledge and experience of medicinal plants than the Muong. They use many more species for disease treatment compared to the number of plant species used by Muong people in the research area. Knowledge of using medicinal plants to treat disease is also different. 83 species have similar medicinal uses, while there are 11 species having at least one medical use that is the same among the Muong and Dao, although one of them (Muong or Dao) may use it for other treatments. An additional 23 medicinal plant species are used by both the Muong and Dao, but there are no similarities in the medicinal uses.

Acknowledgements: The author is grateful to Rufford Small Grants program for financial support to carry out this research project. I am very grateful to the many staff members and local inhabitants in $\mathrm{Ba}$ Vi National Park for their support of our activities, especially Mr. Nguyen Van Tam, Mr. Nguyen Huu Duc, Mrs. Nguyen Thi Lan. We also would like to thank Mr. Phan Van Dung and Miss Nguyen Thi Duyen and other young lecturers and students at the Vietnam Forestry University for their assistance in the field.

\section{REFERENCES}

1. Vo Van Chi, 1996. The dictionary of medicinal plants of Vietnam. Medical Publishing House, Hanoi.

2. Pham Hoang Ho, 2000. The illustrated Flora of Vietnam. Youth Publisher, Hochiminh, Vietnam (in Vietnamese).

3. Trieu Van Hung (ed.), 2007. Non timber forest products in Vietnam. Agricultural Publishing House, Hanoi, Vietnam (in Vietnamese). 
4. Do Tat Loi, 1995. Medicinal trees and medicaments of Vietnam. 7th ed. Science and Technology Publishing House, Hanoi.

5. Martin G. J., 1995. Ethnobotany: A methods manual. Chapman \& Hall, London.

6. Nguyen Ba Ngai, 2001. Methodology of rural appraisal. Vietnam Forestry University, Vietnam (in Vietnamese).

7. Hoang Van Sam, P. Baas \& P. J. A. Keßler, 2008. Traditional medicinal plants in Ben En National Park, Vietnam. Blumea, 53: 569-601.
8. Slikkerveer L. J., 1999. Ethnoscience, 'TEK' and its application to conservation. In: D.A. Posey (ed.), Cultural and spiritual values of biodiversity: 169-180. UNEP, Nairobi, Kenya.

9. Van Andel T. R., 2000. Non-timber forest products in the north-west district of Guyana. Tropenbos-Guyana series 8 . Wageningen.

10. Van Valkenburg, J. L. C. H. \& N. Bunyapraphatsara, 2001. Prosea, Vol. 12, Medicinal and poisonous plants. Backhuys Publishers, Leiden.

\title{
NGHIÊN CÚU TRI THỨC BẢN ĐỊA CỦA NGƯờI DÂN TộC DAO VÀ MƯờNG TRONG SỬ DỤNG CÂY THUỐC TẠI VƯờN QUỐC GIA BA Vİ, HÀ NộI
}

\author{
Hoàng Văn Sâm \\ Trường đại học Lâm nghiệp
}

\section{TÓM TẮT}

Bài báo là kết quả nghiên cứu kiến thức bản địa của người dân tộc Dao và Mường trong sử dụng cây thuốc tại vườn quốc gia $\mathrm{Ba}$ Vì. Nghiên cứu đã bước đầu ghi nhận được tổng số 257 loài thuộc 204 và 81 họ thực vật được người Dao và Mường tại khu vực nghiên cứu sử dụng làm thuốc để chữa trị 63 bệnh khác nhau. Trong tổng số 257 loài thực vật, người Dao sử dụng 144 loài, người Mường sử dụng 30 loài và 83 loài được cả 2 dân tộc sử dụng. Phụ nữ tại khu vực nghiên cứu có kiến thức về cây thuốc tốt hơn nam giới và họ cũng là đối tượng chính thu hái và sơ chế thuốc nam. Kiến thức bản địa trong sử dụng cây thuốc để chữa bệnh giữa người Dao và người Mường tại địa phương cũng có sự khác biệt. Người Dao tại $\mathrm{Ba}$ Vì sử dụng nhiều cây thuốc để chữa trị bệnh hơn là người Mường. Bên cạnh sự khác nhau về số lượng loài sử dụng thì cách ứng dụng các loài trong chữa trị bệnh cũng có sự khác nhau. Có 11 loài có ít nhất một sự khác nhau trong chữa trị bệnh và 23 loài hoàn toàn được sử dụng khác nhau giữa hai dân tộc.

Từ khóa: Cây thuốc, dân tộc Dao, dân tộc Mường, tri thức bản địa, vườn quốc gia Ba Vì.

Ngày nhận bài: 11-7-2011 